Teologia i Moralność, volumen 12(2017), numer 2(22)

doi: 10.14746/tim.2017.22.2.15

ANDRZEJ PRYBA

Uniwersytet im. Adama Mickiewicza w Poznaniu

Wydział Teologiczny

\title{
Odpowiedzialność rodziny za dar życia ludzkiego
}

Czasy, w których żyjemy, są nieprzychylne życiu ludzkiemu. Jest ono bowiem zagrożone w sposób wyjątkowy. To zagrożenie odnosi się do jego istnienia $\mathrm{w}$ ogóle, jak również do jego godności. Zwracał na tę kwestię uwagę św. Jan Paweł II w encyklice Evangelium vitae. Pisał wówczas o zorganizowanym zamachu na życie: „Ten obraz pełen świateł i cieni powinien nam w pełni uświadomić, że stoimy wobec nadludzkiego, dramatycznego zmagania ze złem i dobrem, miedzy śmiercią i życiem, między «kulturą śmierci» i «kulturą życia». Jesteśmy nie tylko świadkami, ale nieuchronnie zostajemy wciągnięci w tę walkę: wszyscy w niej uczestniczymy i stąd nie możemy uchylić się od obowiązku bezwarunkowego opowiedzenia się po stronie życia"”.

\section{Prawda o życiu}

Chrystus objawia w swej Osobie pełną prawdę o ludzkim życiu. Co więcej, dzieląc się nią poprzez swoją Miłość, uzdalnia człowieka do „czynienia tej prawdy”. Jak zauważył papież, to Chrystus staje się „Ewangelią życia”. To On wzywa człowieka ,do przyjęcia i pełnej realizacji obowiązku miłowania ludzkiego życia i służenia mu, bronienia go i wspomagania"3. To dzięki Chrystusowi, żywej Ewangelii możemy poznać, że życie ludzkie jest zawsze dobrem i jest ono jednocześnie objawieniem Boga w świecie oraz znakiem Jego obecności ${ }^{4}$. Człowiek bowiem został obdarzony niezwykłą, a jednocześ-

\footnotetext{
${ }^{1} \mathrm{EV}, 28$.

${ }^{2}$ Tamże, 29.

${ }^{3}$ Tamże.

${ }^{4}$ Por. EV, 34.
} 
nie najwyższą godnością, polegającą na zakorzenieniu w wewnętrznej więzi ze Stwórcą. To dzięki niej jaśnieje w człowieku odblask świętości Boga. Dzieje się tak dlatego, że życie ludzkie jest owocem ,specjalnej decyzji Boga i Jego postanowienia, by połączyć człowieka ze Stwórcą szczególną i specyficzną więzią"5. Bóg, ofiarowując życie człowiekowi, udziela mu niejako samego siebie. Daje mu coś z siebie. „Życie, którym Bóg obdarza człowieka, jest czymś więcej niż tylko istnieniem w czasie. Jest dążeniem ku pełni życia; jest zalążkiem istnienia, które przekracza granice czasu: «Bo dla nieśmiertelności Bóg stworzył człowieka - uczynił go obrazem swej własnej wieczności» $(\operatorname{Mdr} 2,23)^{\prime \prime 6}$.

Życie ludzkie jest więc szczególnym darem Boga. Jest ono bowiem przeznaczone do nieśmiertelności, by w Chrystusie człowiek miał udział w pełni miłości Boga ${ }^{7}$ poprzez komunię z Nim, przez poznanie Go i miłowanie ${ }^{8}$. To Bóg jest źródłem i celem życia. To On podarował człowiekowi życie w sposób bezinteresowny oraz sam stał się darem dla człowieka poprzez propozycję swej miłości i przyjaźni na wieki. Z tego wynika, że człowiek tym samym został powołany do bycia darem dla innych ${ }^{9}$ o czym przypomniał Sobór Watykański II: „Człowiek jest jedynym stworzeniem na ziemi, którego Bóg chciał dla niego samego i dlatego człowiek nie może osiągnąć swojej pełni inaczej, jak poprzez bezinteresowny dar z siebie"10. Stąd też życie ludzkie w kontekście powołania, jakie człowiek otrzymał, zwraca uwagę na Boga, który jest Miłością. To miłość określa ostatecznie zadania małżeństwa i rodziny. Zwracał na tę kwestię uwagę św. Jan Paweł II: „Rodzina dlatego otrzymuje misję strzeżenia, objawiania i przekazywania miłości, będącej żywym odblaskiem i rzeczywistym udzielaniem się miłości Bożej ludzkości oraz miłości Chrystusa Pana Kościołowi, Jego Oblubienicy"11. Jak widać, Bóg sam udziela się ludzkości przez dar stworzenia i odkupienia. To On staje się Darem w miłości uzdalniając jednocześnie człowieka do przyjęcia tego Daru. Tu znajduje się najgłębsza racja dla istnienia rodziny opartej na małżeństwie. Jest to Boży zamysł Stwórcy, który chciał, aby ludzkość stała się zjednoczoną komunią Trójcy Świętej oraz by stwarzane przez Boga życie mogło być przyjęte w miłości ${ }^{12}$.

W tej perspektywie lepiej możemy zrozumieć słowa adhortacji Familiaris consortio, ,że istota i zadania rodziny są ostatecznie określone przez mi-

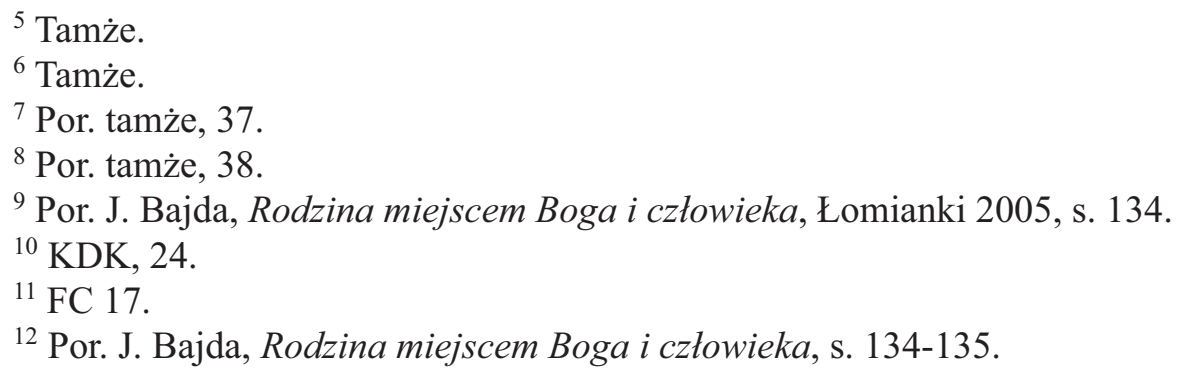


łość"13, a ich najgłębszy sens, jak to zostało już wcześniej ukazane, polega na „strzeżeniu, objawianiu i przekazywaniu miłości”"14. W sumie więc zadania te sprowadzają się, w najbardziej fundamentalnym znaczeniu, do służby życiu, które jest darem Boga. Zdaniem Jerzego Bajdy, „przyjęcie tych zadań i wypełnienie otrzymanej misji jest odpowiedzią, której Bóg oczekuje od małżeństwa i rodziny. Wtedy w rodzinie nie tylko mieszka ta miłość, która zstępuje od Boga jako dar, ale także objawia się miłość, która wraca niejako do Boga w odpowiedzi dziękczynienia i chwały, czyniąc rodzinę żywym Kościołem Boga" ${ }^{15}$. Bogu należy się miłość. Ze strony rodziny miłość polegająca na wzajemnym obdarowaniu, przyjęciu Bożego daru życia i służba jemu, stanowi istotę małżeńsko-rodzinnego powołania. „Odpowiedzialność ta w aspekcie podmiotowym oznacza, że dzieła powierzone przez Boga są wpisane niejako w tożsamość osobowego podmiotu i jednocześnie go określają"16. Możemy tu odnieść się do biblijnej analogii. Podobnie jak Bóg uczynił Abrahama „ojcem wielu narodów" (zob. Rdz 18,18-19), Niepokalaną Maryję Matką Bożego Syna (zob. Łk 1,26-35), a apostoła Piotra Opoką (zob. Mt 16,18-19) widzialnego Kościoła. Stąd Jan Paweł II pisał w swej adhortacji o „wewnętrznej prawdzie istnienia" ${ }^{17}$ rodziny, w której zapisane jest jej powołanie i posłannictwo. Stąd też odrzucenie tej odpowiedzialności równe jest z przekreśleniem swej tożsamości.

W przypadku natomiast odpowiedzialności w aspekcie przedmiotowym chodzi o zakres działań niezbędnych do zrealizowania misji małżeńsko-rodzinnej polegającej na podejmowaniu decyzji etycznych przynależących do osoby.

\section{Odpowiedzialne rodzicielstwo jako wspóldzialanie z Bogiem Stwórcą}

Bóg objawia samego siebie poprzez Słowo. Przychodzi do swojego dzieła w sposób osobowy. Wszystko, co jest - jest Jego obrazem, darem, obecnością. Działanie Boga jest powołaniem, przyjściem, jak również zjednoczeniem. Działanie Boga jest pełnią Prawdy, Życia i Miłości darowaną w Chrystusie. To w Chrystusie wyjaśnia się i wypełnia prawda i tajemnica kosmosu, życia, osoby, wspólnoty i społeczności.

Bóg jest w sobie jeden, zgodny, tożsamy z sobą, kocha prawdę bytów zgodnych oraz pojednanych z sobą. On jest pojednaniem. Jakiekolwiek współ-

\footnotetext{
${ }^{13} \mathrm{FC}, 17$.

${ }^{14}$ Tamże.

${ }^{15}$ J. Bajda, Rodzina miejscem Boga i czlowieka, s. 135.

16 Tamże.

${ }^{17} \mathrm{FC}, 17$.
} 
działanie z Bogiem może mieć tylko tę podstawę, że byt działający jest najpierw zgodny z prawdą na swój temat. Małżeństwo nie współpracuje inaczej z Bogiem, jak przez samo dzieło, które spełnia jako własne, wyrażające jego prawdę i jego misję; przez rodzicielstwo. Małżonkowie mogą więc współdziałać z Bogiem na zasadzie chrystologicznej i sakramentalnej. Bóg, darowując siebie ludzkości w Chrystusie, tym samym darował jej swoje dzieło, gdyż Chrystus jest szczytem i pełnią tego dzieła. To oczywiście zakłada, że człowiek przyjmuje ten dar i odpowiada na niego. W konsekwencji, rozwijając to dzieło jako dar Boga, objawia jednocześnie jego Dawcę, głosi świętość Boga i ujawnia myśl Boga zawartą $\mathrm{w}$ darze ${ }^{18}$.

Przywołaną tu prawdę potwierdza nauczanie Soboru Watykańskiego II, który twierdzi, że małżonkowie przez swoją szlachetną postawę moralną, czyli przez wierne spełnienie swego powołania „ujawniają wszystkim swoją obecność Zbawiciela oraz prawdziwą naturę Kościoła"19. Wymaga to naturalnie traktowania przez małżonków swojego wspólnego życia jako Bożego daru oraz wyrażenia wdzięczności w duchu wiary nadziei i miłości przez całe życie.

Bóg, stwarzając człowieka jako mężczyznę i kobietę, powołuje ich do szczególnego uczestnictwa w swojej miłości. W refleksji dotyczącej powołania małżeństwa i rodziny św. Jan Paweł II zawarł następującą uwagę: „Bóg stwarzając mężczyznę i kobietę na obraz swój i podobieństwo, wieńczy i doprowadza do doskonałości dzieło swych rąk - powołuje ich do szczególnego uczestnictwa w swej miłości, a zarazem w swojej mocy Stwórcy i Ojca poprzez ich wolną i odpowiedzialną współpracę w przekazywaniu życia ludzkiego" 20 .

W analizach dotyczących odpowiedzialności rodziny za życie papież Jan Paweł II nawiązał do tajemnicy stworzenia (początku) i powołania człowieka do udziału w boskim panowaniu nad światem. Obejmuje ono odpowiedzialność za życie, które należy bronić, umacniać, czcić i kochać. Ponadto, jak zauważył papież, w błogosławieństwie Bożym i przykazaniu skierowanym do stwarzanej ludzkości ${ }^{21}$ został zawarty podwójny zakres odpowiedzialności, który dotyczył przymierza mężczyzny i kobiety, czyli małżeństwa. Chodzi tu

${ }^{18}$ Por. J. Bajda, Powolanie malżeństwa i rodziny, w: Teologia malżeństwa i rodziny, t. 1, red. K. Majdański, Warszawa 1980, s. 85-86.

${ }^{19} \mathrm{KDK}, 48$.

${ }^{20}$ FC, 28. Por. M. Kluz, A.S. Słomka, Małżeństwo jako wyraz pelnej realizacji miłości między mężczyzna a kobieta, w: Rodzina między płaca a praca. Refleksja nad społeczna myśla encykliki Laborem exercens Jana Pawła II, red. R. Kantor, M. Kluz, J. Młyński, Kraków 2016, s. 278-282.

${ }^{21}$ „Po czym Bóg im błogosławił, mówiąc do nich: «Bądźcie płodni i rozmnażajcie się, abyście zaludnili ziemię i uczynili ją sobie poddaną; abyście panowali nad rybami morskimi, nad ptactwem powietrznym i nad wszystkimi zwierzętami pełzającymi po ziemi»” ( $\mathrm{Rdz} 1,28)$. 
o odpowiedzialność za życie oraz odpowiedzialność za świat ${ }^{22}$. Te dwa błogosławieństwa: płodności i panowania nad światem, są ze sobą integralnie powiązane i stanowią treść Przymierza, jakie zawarł Bóg z człowiekiem.

Przekazywanie życia winno być realizowane na podstawie planu Bożej Mądrości i Miłości wyrażonego w stworzeniu małżeństwa i ludzkości. Ponadto winno ono nawiązywać do zbawczego powołania małżonków i rodziny w Kościele wspartego na właściwej hierarchii wartości, na której opiera się budowanie życia ludzkiego.

Etyczny profil odpowiedzialności rodziny za dar życia jest zakorzeniony w jej istocie,

opartej na wewnętrznym przenikaniu się dwóch aspektów Przymierza (także jako sakramentu): komunii osób (ustanowionej przez Boga jako «jedno ciało») komunii związanej relacją oblubieńczą, oraz wymiaru rodzicielskiego, wpisanego w najgłębszą istotę tejże relacji oblubieńczej mężczyzny i kobiety (męża i żony). Nierozdzielność tych dwóch aspektów jest podstawą dla norm etycznych określających prawdę moralną działania małżeńskiego ${ }^{23}$.

Uwzględniając dotychczasowy tok rozumowania, należy stwierdzić za Jerzym Bajdą, że ,planowanie rodziny polega na ciągu etycznych decyzji mających na celu urzeczywistnienie kształtu rodziny w sposób możliwie najlepiej odpowiadający Ojcowskiej woli samego Boga, istocie powołania małżeńskiego i wymiarowi obowiązującej małżonków miłości i wielkoduszności"24.

Podejmowane przez małżonków akty winny być symbolem bezinteresownego daru własnej osoby, jak tego domaga się istota małżeństwa rozumianego jako communio personarum, w poczuciu pełnej i wielkodusznej odpowiedzialności, wynikającej z miłości rodzicielskiej. Takie decyzje winny być równocześnie przeżywane jako akt współdziałania ze Stwórcą i Jego miłością, co oznacza gotowość pełnienia woli Boga oraz oddania swej woli na służbę Jemu w duchu nadprzyrodzonej odpowiedzi wiary. Stąd odpowiedzialność małżonków jest związana również z zaufaniem wobec Jego Miłości. Przecież człowiek nie może przewidzieć swojej przyszłości. Po ludzku jednak biorąc, w każdej decyzji rodzicielskiej kryje się pewne ryzyko. Tym, który zna przyszłość, jest Bóg i Jemu należy się całkowite zawierzenie własnej przyszłości. Bez tego oparcia się na Bogu, każda decyzja dotycząca ludzkiej płodności jest nieodpowiedzialna ${ }^{25}$.

${ }^{22}$ Por. EV, 42.

${ }^{23}$ J. Bajda, Rodzina miejscem Boga i człowieka, s. 136-137.

${ }^{24} \mathrm{~J}$. Bajda, Powołanie matżeństwa i rodziny, s. 105.

${ }^{25}$ Por. A. Pryba, Planowanie rodziny a więź matżeńska, Olsztyn 2002, s. 36. 
Małżonkowie winni więc być odpowiedzialni za życie od momentu poczęcia. Odpowiedzialność ta wynika z niezwykłej godności życia, które ma swoje źródło w Bogu, „czego świadectwo można znaleźć na wielu stronach Biblii, która ze czcią i miłością mówi o poczęciu, o kształtowaniu się życia w łonie matki, o narodzinach i o ścisłej więzi, jaka zachodzi między pierwszą chwilą istnienia a działaniem Boga Stwórcy"26. W tym kontekście o człowieku można powiedzieć, że jest on sługą i strażnikiem tajemnicy życia, która została powierzona małżeństwu. Jak znakomicie tłumaczył Jan Paweł II: „Człowiek nie jest panem śmierci, tak jak nie jest panem życia; w życiu i śmierci musi zawierzyć się całkowicie «Woli Najwyższego», zamysłowi Jego miłości"27. Stąd też w dalszej części swego wywodu dotyczącego obrony życia ludzkiego papież jednoznacznie stwierdził, że „,nic i nikt nie może dać prawa do zabicia niewinnej istoty ludzkiej, czy to jest embrion czy płód, dziecko czy dorosły, człowiek stary, nieuleczalnie chory, czy umierający"28. Jakże więc tragiczna jest sytuacja, kiedy decyzję zabiciu dziecka poczętego podejmują sami rodzice. W konsekwencji takiego działania ,rodzina zostaje śmiertelnie zraniona i zbezczeszczona w swej naturze, jako wspólnota miłości oraz w swym powołaniu, jako «sanktuarium życia»"29. A przecież rodzina ,jest powołana, aby spełniać swoje zadania, w ciągu całego życia swych członków, od narodzin do śmierci. Jest prawdziwym sanktuarium życia [...] miejscem, w którym życie, dar Boga, może w sposób właściwy być przyjęte i chronione przed licznymi atakami, na które jest ono wystawione" ${ }^{\text {30 }}$. Te zadania spoczywają na małżonkach, którzy są wezwani, aby być przekazicielami życia na podstawie odnawianej świadomości sensu rodzicielstwa, pojmowanego jako doniosłe wydarzenie, ukazujące, że życie ludzkie jest darem, który przyjmujemy po to, aby go ponownie ofiarować. Rodząc nowe życie, rodzice przekonują się, że dziecko, choć jest owocem ich wzajemnego daru miłości, jest zarazem darem dla obojga, darem, który wypływa z daru"31. Aby więc w pełni zrozumieć prawdę rodzicielstwa, potrzeba uznania faktu, że „w ludzkim rodzicielstwie sam Bóg jest obecny - obecny w inny jeszcze sposób niż to ma miejsce w każdym innym rodzeniu w świecie widzialnym «na ziemi». Przecież od Niego tylko może pochodzić «obraz i podobieństwo», które jest właściwe istocie ludzkiej, tak jak przy stworzeniu. Rodzenie jest kontynuacją stworzenia"32.

${ }^{26} \mathrm{EV}, 44$.

${ }^{27}$ EV, 46. Papież Paweł VI w encyklice „Humanae vitae” w numerze 13 stwierdza, że człowiek jest „sługą planu ustalonego przez Stwórcę” i właśnie na tym polega jego wielkość.

${ }^{28} \mathrm{EV}, 57$.

${ }^{29} \mathrm{EV}, 59$.

${ }^{30} \mathrm{EV}, 92$.

${ }^{31}$ Tamże.

${ }^{32} \mathrm{EV}, 43$. Por. A. Bohdanowicz, Odpowiedzialne rodzicielstwo wedtug papieża Pawła VI we współczesnym nauczaniu moralnym Kościoła, „Teologia i Moralność” 2(20) 2016, s. 182. 
Co to oznacza w praktyce? Plan Boga Stwórcy został wyrażony w naturze aktu małżeńskiego, czyli w biologicznej płodności i niepłodności. Jest to centralna zasada etyczna sformułowana w encyklice papieża Pawła VI Humanae vitae. Papież stwierdził, że jest konieczną rzeczą, ,aby każdy akt małżeński zachował swoje wewnętrzne przeznaczenie do przekazywania życia ludzkiego"33. "Nauka ta ma swoją podstawę w ustanowionym przez Boga nierozerwalnym związku między dwojakim znaczeniem tkwiącym w stosunku małżeńskim: między oznaczeniem jedności i oznaczeniem rodzicielstwa (albowiem stosunek małżeński z najgłębszej swej istoty, łącząc najściślejszą więzią męża i żonę, jednocześnie czyni ich zdolnymi do zrodzenia nowego życia, zgodnie z prawami zawartymi w naturze mężczyzny i kobiety"34. Łączność jedności i płodności stanowi więc normę moralną, tj. normę postępowania. „Zachowanie tej natury w każdym zbliżeniu małżeńskim jest wykładnią wierności wobec planu Bożego"35, albowiem taka natura aktu małżeńskiego wyraża wolę Stwórcy. Stąd też istotną kwestią jest decyzja małżonków dotycząca poczęcia dziecka: „tak” albo „nie”. Chodzi tu o etyczne rozporządzanie sobą jako źródłem życia.

\section{Decyzja rodzicielska jako wewnętrzny element dialogu małżeńskiego}

Dialog $^{36} \mathrm{w}$ małżeństwie jest niezwykle istotnym czynnikiem. To dzięki niemu dwoje ludzi może się wzajemnie porozumieć i zrozumieć. Oprócz tego mogą się oni również bardziej poznać. To z kolei będzie miało wpływ na podejmowane przez nich decyzje. Autentyczna komunikacja pomiędzy mał-

${ }^{33} \mathrm{HV}, 11$.

${ }^{34} \mathrm{HV}, 12$.

${ }^{35} \mathrm{HV}, 13$.

36 „Pojęcie dialog kryje w sobie głęboką treść i obejmuje swym zakresem wiele płaszczyzn ludzkiego życia, zarówno jednostkowego i osobistego, jakizbiorowego i publicznego. Wydaje się, iż jest ono swoistym kluczem, z pomocą którego ludzie nawiązują z sobą styczności i więzi, ułatwiają sobie wzajemnie codzienne życie i współbycie, organizują sobie współżycie w różnych wspólnotach i grupach celowych. Jednakże jest ono także metoda na zachowanie swojej tożsamości pośród innych jednostek i w różnych zbiorowościach, czyli jest sposobem na bycie sobą dla siebie i dla innych w odmiennych okolicznościach życia. Pojęcie to (dialog) uwrażliwia nas na złożoność i głębię rzeczywistości, którą sobą symbolizuje, wyraża i preferuje, a bez której życie ludzi byłoby co najmniej bardzo utrudnione. Głębia hermetyczna tego pojęcia skłania każdorazowo do zapytania, czym w swej istocie jest dialog człowieka z człowiekiem, ludzi z ludźmi, wkomponowany w kontekst sytuacji i okoliczności ich życia? Te okoliczności determinują istotnie dialog, nadają mu swoistą barwę czy określony koloryt, są czynnikami warunkującymi jego realność i konieczność egzystencjalną. Na tej podstawie mówimy też o różnych typach dialogu czy o jego zakresach znaczeniowych, dostrzegamy jego wpływ na różne płaszczyzny naszego życia" - J. Baniak, Dialog w malżeństwie i rodzinie jako czynnik więzi i trwałości wspólnotowej, „Poznańskie Studia Teologiczne” 14 (2003), s. 175. 
żonkami jest istotną częścią ich wzajemnych relacji. Zacieśnia ona bowiem obopólną więź, usprawnia porozumienie, jak również pomaga im wzrastać w miłości. Stąd też funkcjonowanie małżeństwa i rodziny zależy w głównej mierze od jakości dialogu małżeńskiego ${ }^{37}$.

Żeby jednak dialog był udany, dwie osoby muszą przede wszystkim ze sobą rozmawiać, ale dobra komunikacja powinna też spełniać podstawowe warunki. Pośród nich należy wymienić otwartość i empatię. Ponadto, jak zauważa Maria Braun-Gałkowska, aby

rozmowa była udana, powinna w niej być otwartość, szczerość, przeźroczystość. Jeżeli ktoś chce wywołać określone zachowanie drugiej osoby manipulując nią, a nie mówiąc wprost, o co mu chodzi, uniemożliwia prawdziwą komunikację. Potrzebne jest więc jasne wyrażanie swoich przeżyć, a po drugie: trafne, można by powiedzieć - troskliwe, odbieranie sygnałów od partnera interakcji. Oczywiście, jakość komunikacji zależy od obu stron. Cechy dobrej komunikacji dotyczą każdego jednocześnie, bo wielokrotnie, w czasie jednej rozmowy, trzeba być jednocześnie przeźroczystym przy mówieniu i empatycznym przy słuchaniu. Komunikacja polega nie tylko na jednostronnym nadawaniu, ale również na odbieraniu informacji i sprawdzaniu, czy zrozumiało się ją prawidłowo ${ }^{38}$.

Prawidłowa komunikacja zakłada więc jasność przekazu, będącą wyrażaniem myśli w sposób jednoznaczny i zrozumiały. Ważne jest również udzielanie informacji w sposób bezpośredni. Otwartość jest ujawnieniem się własnych przeżyć, emocji, potrzeb oraz doświadczeńn ${ }^{39}$. Komunikacja jednak zależna jest $\mathrm{w}$ dużym stopniu od nastawienia uczuciowego małżonków. W przypadku pozytywnego nastawienia powoduje głębsze otwarcie się na współmałżonka, zainteresowanie się nim oraz uważne słuchanie racji, jakie przedstawia. Taka postawa sprzyja zdecydowanie wymianie myśli. W przypadku jednak negatywnego nastawienia małżonkowie wzajemnie unikają kontaktu, selektywnie słuchają, wychwytują potknięcia i wyolbrzymiają je. W przypadku negatywnego nastawienia można zauważyć również brak troski o zrozumienie drugiej strony, jak również łatwe okazywanie zniecierpliwienia. Trudno w takich sytuacjach o jakiekolwiek porozumienie ${ }^{40}$.

W związkach osób wierzących prowadzenie rozmów ułatwia praktyka wspólnej modlitwy. Nawiązanie relacji z Bogiem skłania do autentycznego

${ }^{37}$ Por. S. Biel, Komunikacja malżeńska kluczem wychowania do dialogu - sprawozdanie z badań, „Edukacja Elementarna w Teorii i Praktyce” 29/3 (2013), s. 33.

${ }^{38}$ M. Braun-Gałkowska, Dialog w rodzinie, „Pedagogia Christiana” 1(25) 2010, s. 165-166.

${ }^{39}$ Por. J. Laskowski, Matżeństwo wspólnota miłości, Warszawa 1993, s. 118; M. Ryś, Konflikty w rodzinie niszcza czy budują?, Warszawa 1994, s. 33.

${ }^{40}$ Por. W. Gasidło, Z zagadnień etyki matżeńskiej, Kraków 1990, s. 127. 
wejścia w siebie, uznania własnej grzeszności i ułomności, wybaczania oraz proszenia o wybaczenie. W życiu chrześcijańskim zarówno miłość do Boga, jak i miłość do drugiego człowieka są ze sobą istotnie zjednoczone. Dlatego też modlitwa, podczas której nawiązuje się relację i więź z żywym Bogiem, powinna promieniować na więź międzyosobową poprzez podejmowanie i rozwijanie żywego dialogu. Ma on zasadnicze znaczenie dla małżeństwa przeżywanego jako wspólnota miłości. Autentyczny dialog ubogaca jego uczestników, pomnaża radość i osłabia napięcia ${ }^{41}$.

Winien dotyczyć także pożycia małżeńskiego. Aby było ono zgodne z Bożym zamysłem, małżonkowie winni respektować prawo naturalne. Chodzi o to, aby małżonkowie byli świadomi okresów płodności i niepłodności, by, znając je, wspólnie podejmowali decyzje w sprawie kontaktów seksualnych. Uzgodnienie współżycia intymnego z rytmem płodności wymaga z kolei od małżonków słownego porozumiewania, uzgadniania terminów współżycia, co w konsekwencji uczy powściągliwości, bez której prawdziwa wierność motywowana jest tylko poczuciem obowiązku ${ }^{42}$.

Dialog małżeński może inspirować rozmowę z Bogiem, a ta z kolei powinna skłaniać do dialogu ze współmałżonkiem. Decyzja o poczęciu dziecka winna być podejmowana wspólnie. Dialog na ten temat winien odbywać się z Bogiem poprzez modlitwę oraz rozeznanie duchowe. Dotyczy to również sprawy poczęcia. Małżonkowie powinni odczytywać również i w tej sprawie myśl Bożą w ciągu całego swego życia.

Rozporządzanie płodnością należy do głównych czynników pielęgnowania więzi małżeńskiej. W przypadku naturalnych metod rozporządzania płodnością zakładają one liczenie się z płodnością osoby i pary ludzkiej zależnie od naturalnego rytmu hormonalnego kobiety.

Liczenie się z tym rytmem, dostosowanie do niego współżycia seksualnego jest tym samym, co dbałość o zgodę w ważnych kwestiach o atmosferę uczuciową, o prawidłową komunikację międzyosobową w małżeństwie. Takie pielęgnowanie więzi, jak gospodarzenie płodnością wymagają wysiłku wyuczenia. W pielęgnowaniu więzi bardzo ważna jest zdolność obserwowania reakcji emocjonalnych współmałżonka, odczytywanie jego/jej oczekiwań lub dopytywanie się o nie, dostrzeganie potrzeb, obaw, wahań uczuciowych. W gospodarzeniu płodnością jest podobnie: uważność kieruje się ku funkcjom organizmu i jego cyklicznym przemianom, obserwacjom tych elementów codzienności, które nasilają bądź tłumią pobudliwość seksualną ${ }^{43}$.

${ }^{41}$ Por. A. Pryba, Planowanie rodziny a więź matżeńska, Olsztyn 2002, s. 38.

${ }^{42}$ Por. E. Sujak, Malżeństwo pielęnowane, Katowice 1989, s. 97, 107.

${ }^{43}$ E. Sujak, Wprowadzenie, w: T. Kramarek, Naturalne planowanie rodziny i jego biologiczne uwarunkowania, Poznań 1997, s. 9. 
Obserwacje płodności łączą małżonków określoną wspólnotą celów. Mają oni świadomość, że są płodni oboje jako małżeństwo. Przyczynia się to do tworzenia ich wzajemnej więzi. Kontakty małżeńskie mają charakter wzajemnej, osobowej wymiany uczuć. Stosowanie więc przez małżonków naturalnego planowania rodziny, zgodnie z Bożym zamysłem, wymaga z jednej strony silnej więzi, z drugiej natomiast więź tę wzmacnia. Ponadto przyjmując taką postawę, małżonkowie zachowują się odpowiedzialnie względem samych siebie, jak również wobec ewentualnego poczęcia dziecka, autentycznego owocu ich wzajemnej miłości polegającej na wzajemnym oddaniu się sobie.

Odpowiedzialne rodzicielstwo polegające na uszanowaniu naturalnego rytmu płodności i niepłodności oznaczonego w cyklu kobiecym odgrywa ważną rolę w budowaniu trwałej i wyłącznej więzi małżeńskiej.

Wybór rytmu naturalnego bowiem pociąga za sobą akceptację osoby, to jest kobiety, a co za tym idzie akceptację dialogu, wzajemnego poszanowania, wspólnej odpowiedzialności, panowania nad sobą. Przyjęcie cyklu i dialogu oznacza następnie uznanie charakteru duchowego i cielesnego zarazem komunii małżeńskiej, jak również przeżywanie miłości osobowej w wierności jakiej ona wymaga. W tym kontekście para małżeńska ubogaca się takimi wartościami, jak czułość i serdeczność, które są czynnikami głęboko ożywiającymi płciowość ludzką, również w jej wymiarze fizycznym ${ }^{44}$.

Konkludując, trzeba podkreślić, że życie zgodne z naturalnym rytmem płodności powoduje pogłębienie miłości małżeńskiej, wytwarza atmosferę wzajemnego szacunku oraz styl otwartej i szczerej komunikacji, zwiększa jakość przeżyć seksualnych, wzbudza szacunek dla życia ludzkiego, buduje zgodę i harmonię życia rodzinnego, co z kolei pogłębia ich wzajemną więź ${ }^{45}$. Ponadto istotą decyzji rodzicielskiej o przekazaniu życia jest decyzja etyczna, która ma za przedmiot dobro moralne, przez który czyn małżonków staje się sam w sobie godziwy. Wartość czynu nie wynika z jego skutku, pragmatyczności czy przydatności do osiągnięcia postawionego celu. To wartość moralna aktualizuje się na płaszczyźnie miłości w kontekście powołania małżeńskiego. $\mathrm{Z}$ istoty tego powołania z kolei wynika, że decyzja ta w swojej istocie jest rodzicielska, niezależnie od tego, czy aktualnie może doprowadzić do poczęcia dziecka. Realizacja przez małżonków Bożego zamysłu wobec nich prowadzi w konsekwencji do odpowiedzialności za swoje działanie, jak również za każde życie ludzkie.

\footnotetext{
${ }^{44} \mathrm{FC}, 32$.

45 Por. A. Pryba, Planowanie rodziny a więź matżeńska, s. 39-40.
} 


\section{RESPONSIBILITY OF THE FAMILY FOR THE GIFT OF HUMAN LIFE}

\section{Summary}

Human life is endangered. In the modern world, there is a confrontation between the "culture of life" and the "culture of death". How should a person behave in this context? He should choose life. This attitude results from the truth that God himself is the creator of human life and its nature. Man as a man and woman received a special vocation to live in marriage and family. It is in them that creation of a community of life and love is to take place. Marriage is the foundation for the family. Parenthood, in turn, should be the fruit of mutual spouses' personal giving and their cooperation with God the Creator. Parental decision, on the other hand, should be an internal element of a marital dialogue. The implementation of God's plan for marriage and family leads to respect for human life and responsibility for it.

Słowa kluczowe: małżeństwo; rodzina; życie ludzkie; odpowiedzialne rodzicielstwo

Keywords: marriage; family; human life; responsible parenthood

\section{BIBLIOGRAFIA}

Bajda J., Powołanie malżeństwa i rodziny, w: Teologia malżeństwa i rodziny, t. 1, red. K. Majdański, Warszawa 1980, s. 7-156.

Bajda J., Rodzina miejscem Boga i człowieka, Łomianki 2005.

Baniak J., Dialog w matżeństwie i rodzinie jako czynnik więzi i trwatości wspólnotowej, „Poznańskie Studia Teologiczne" 14 (2003), s. 175-212.

Biel S., Komunikacja małżeńska kluczem wychowania do dialogu - sprawozdanie z badań, „Edukacja Elementarna w Teorii i Praktyce" 29/3 (2013), s. 33-56.

Bohdanowicz A., Odpowiedzialne rodzicielstwo wedtug papieża Pawła VI we wspótczesnym nauczaniu moralnym Kościoła, „Teologia i Moralność” 2(20) 2016, s. 181-190.

Braun-Gałkowska M., Dialog w rodzinie, „Pedagogia Christiana” 1(25) 2010, s. 161-173.

Gasidło W., Z zagadnień etyki małżeńskiej, Kraków 1990.

Jan Paweł II, Adhortacja apostolska Familiaris consortio, Rzym 1981.

Jan Paweł II, Encyklika Evangelium vitae, Rzym 1995.

Kluz M., Słomka A.S., Malżeństwo jako wyraz petnej realizacji miłości między mężczyzna a kobieta, w: Rodzina między płaca a praca. Refleksja nad spoleczna myśla encykliki Laborem exercens Jana Pawła II, red. R. Kantor, M. Kluz, J. Młyński, Kraków 2016, s. 273-300.

Laskowski J., Matżeństwo wspólnota miłości, Warszawa 1993.

Paweł VI, Encyklika Humanae vitae, Rzym 1968.

Pryba A., Planowanie rodziny a więź malżeńska, Olsztyn 2002.

Ryś M., Konflikty w rodzinie niszcza czy buduja??, Warszawa 1994.

Sobór Watykański II, Konstytucja duszpasterska o Kościele w świecie współczesnym Gaudum et spes, Rzym 1965. 
Sujak E., Mał̇eństwo pielęgnowane, Katowice 1989.

Sujak E., Wprowadzenie, w: T. Kramarek, Naturalne planowanie rodziny i jego biologiczne uwarunkowania, Poznań 1997, s. 9.

AndrzeJ PrybA - kapłan Zgromadzenia Misjonarzy Świętej Rodziny, doktor habilitowany nauk teologicznych w zakresie teologii moralnej. Adiunkt w Zakładzie Teologii Moralnej, Duchowości i Katolickiej Nauki Społecznej Wydziału Teologicznego Uniwersytetu im. Adama Mickiewicza w Poznaniu. Członek Stowarzyszenia Teologów Moralistów oraz Polskiego Stowarzyszenia Familiologicznego. Główne kierunki badań to problematyka związana z teologią małżeństwa i rodziny, poradnictwa rodzinnego oraz katolickiej nauki społecznej w odniesieniu do małżeństwa i rodziny. 